\title{
2010s-14 \\ The Determinants of Education-Job Match among Canadian University Graduates
}

\author{
Brahim Boudarbat, Victor Chernoff
}

\begin{tabular}{c}
\hline Série Scientifique \\
Scientific Series
\end{tabular}

\section{Montréal \\ Mars 2010}

(C) 2010 Brahim Boudarbat, Victor Chernoff. Tous droits réservés. All rights reserved. Reproduction partielle permise avec citation du document source, incluant la notice (C).

Short sections may be quoted without explicit permission, if full credit, including (C) notice, is given to the source.
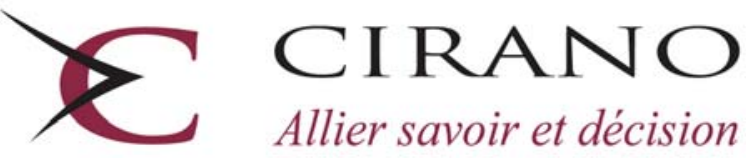

Allier savoir et décision

Centre interuniversitaire de recherche en analyse des organisations 


\section{CIRANO}

Le CIRANO est un organisme sans but lucratif constitué en vertu de la Loi des compagnies du Québec. Le financement de son infrastructure et de ses activités de recherche provient des cotisations de ses organisations-membres, d'une subvention d’infrastructure du Ministère du Développement économique et régional et de la Recherche, de même que des subventions et mandats obtenus par ses équipes de recherche.

CIRANO is a private non-profit organization incorporated under the Québec Companies Act. Its infrastructure and research activities are funded through fees paid by member organizations, an infrastructure grant from the Ministère du Développement économique et régional et de la Recherche, and grants and research mandates obtained by its research teams.

\section{Les partenaires du CIRANO}

\section{Partenaire majeur}

Ministère du Développement économique, de l'Innovation et de l'Exportation

\section{Partenaires corporatifs}

Banque de développement du Canada

Banque du Canada

Banque Laurentienne du Canada

Banque Nationale du Canada

Banque Royale du Canada

Banque Scotia

Bell Canada

BMO Groupe financier

Caisse de dépôt et placement du Québec

DMR

Fédération des caisses Desjardins du Québec

Gaz Métro

Hydro-Québec

Industrie Canada

Investissements PSP

Ministère des Finances du Québec

Power Corporation du Canada

Raymond Chabot Grant Thornton

Rio Tinto

State Street Global Advisors

Transat A.T.

Ville de Montréal

\section{Partenaires universitaires}

École Polytechnique de Montréal

HEC Montréal

McGill University

Université Concordia

Université de Montréal

Université de Sherbrooke

Université du Québec

Université du Québec à Montréal

Université Laval

Le CIRANO collabore avec de nombreux centres et chaires de recherche universitaires dont on peut consulter la liste sur son site web.

Les cahiers de la série scientifique (CS) visent à rendre accessibles des résultats de recherche effectuée au CIRANO

afin de susciter échanges et commentaires. Ces cahiers sont écrits dans le style des publications scientifiques. Les idées

et les opinions émises sont sous l'unique responsabilité des auteurs et ne représentent pas nécessairement les positions

du CIRANO ou de ses partenaires.

This paper presents research carried out at CIRANO and aims at encouraging discussion and comment. The observations and viewpoints expressed are the sole responsibility of the authors. They do not necessarily represent positions of CIRANO or its partners. 


\title{
The Determinants of Education-Job Match among Canadian University Graduates*
}

\author{
Brahim Boudarbat ${ }^{\dagger}$, Victor Chernoff $f^{*}$
}

\begin{abstract}
Résumé
Cette étude utilise les données de l'Enquête de suivi auprès des diplômés de la promotion de 2000, réalisée en 2005. L’objectif est d'examiner les déterminants de la correspondance entre le programme d'études complété et l'emploi obtenu par les diplômés universitaires canadiens. D’une perspective de politiques publiques, la question de la correspondance entre les études et l'emploi est pertinente compte tenu de l'importante des moyens investis par la société canadienne dans ses institutions d'enseignement postsecondaire, ainsi que le rôle dévoué au capital humain dans le développement économique. Nos résultats indiquent qu'un diplômé sur trois (35,1\%) est dans un emploi qui n'est pas étroitement lié à ses études. Toutefois, le résultat le plus important est que les caractéristiques démographiques et socio-économiques des diplômés (sexe et background familial) n'affectent pas de manière significative la probabilité d'obtenir un emploi correspondant à ses études. Ce sont les caractéristiques du programme d'études (niveau et domaine) qui influencent fortement cette probabilité. Les diplômés des domaines d'études à caractère spécifique comme la santé et l'éducation sont les plus susceptibles d'obtenir un emploi qui correspond à leurs études. En outre, un niveau de scolarité élevé (deuxième ou troisième cycles), ainsi que de bonnes notes, ont un grand effet positif sur la probabilité d'accéder à un emploi en adéquation avec les études. Les caractéristiques de l'emploi affectent également cette adéquation, mais dans une mesure contrastée, avec certaines caractéristiques, comme l'industrie et le travail à temps plein, qui ont un effet significatif, tandis que d'autres, telles que la permanence de l'emploi et la méthode utilisée pour obtenir un emploi, qui n’ont pas d’effet significatif.
\end{abstract}

Mots clés : correspondance études-emploi; diplômés universitaires; Canada; Enquête de suivi auprès des diplômés.

\footnotetext{
${ }^{*}$ The authors would like to thank Jean-Michel Cousineau and Vincent Rousseau for valuable comments and suggestions. Many thanks go also to Statistics Canada and the Quebec Inter-University Centre for Social Statistics for providing data used in this study, and for technical support.

† School of Industrial relations, Université de Montréal; C.P. 6128, succursale Centre-ville, Montreal (Quebec) H3C 3J7, Canada. Email: brahim.boudarbat@umontreal.ca

‡ Université de Montréal.
} 


\begin{abstract}
This study uses data from the Follow-up of Graduates Survey - Class of 2000, to look at the determinants of education-job match among Canadian university graduates. From a public policy perspective, the question of education-job match is relevant given the substantial investment society puts into its postsecondary institutions, and the role devoted to human capital in economic development. Our results indicate that one graduate out of three (35.1\%) is in a job that is not closely related to his or her education. The most important result is that demographic and socioeconomic characteristics (gender and family background) do not significantly affect the match. On the other hand, education characteristics strongly influence match, with field specific programs (such as "Health sciences" and "Education") having the highest likelihood of obtaining an education-job match. In addition, the level of education (i.e. graduates with a postgraduate degree vs. a bachelor degree), as well as good grades, strongly affect the match. Employment characteristics also affect the match, but to a mixed extent, with certain characteristics, such as industry, as well as working full-time (vs. part time) affecting the match to a strong extent, while others, such as the permanence of employment, as well as the method used to obtain employment, not having a significant effect on match.
\end{abstract}

Keywords: education-job match; university graduates; Canada; Follow-up of Graduates Survey. 


\section{Introduction}

Canada has kept up with and even surpassed the already tremendous international growth in postsecondary education that western countries have experienced since World War II. In 2006, $27.9 \%$ of Canada's working age population (25 to 64) had a university degree, certificate, or diploma, up from $22.6 \%$ in 2001, and $12.9 \%$ in 1981. The proportion of Canada's working age population with college credentials has also increased substantially, going from 17.9\% in 2001 to 20.3\% in 2006 (Canadian census data). Owram (1996) attributes Canada's rise in postsecondary education to its expansion in white collar positions in the 1950s through to the 1970s, requiring it to have more teachers, civil servants, nurses, and bankers; at this time, Canada's middleclass population began to view the obtainment of postsecondary credentials as being a necessary tool for success. Roterman (1999) describes how in the 1950s and 1960s, a strong postwar economy and the relatively scarce number of university graduates meant that all fields had labour market success. However, as time passed and economic conditions declined, universities became more heavily scrutinized in terms of how they were funded, and as a response to this, money was reinvested into more job-specific programs.

From society's point of view, the initial costs of education are expensive. In 2006, expenditure on education from public and private sources represented 6.5\% of GDP in Canada (OECD, 2009). Private costs become very high in postsecondary education as they include not only the direct costs of enrolment and class material, but also indirect costs (foregone earnings). On average, a Canadian individual spends more than USD 50,000 to acquire a tertiary qualification, that is to say, $46.6 \%$ of total costs (OECD, 2009). Such investment is, however, important to sustain the country's development and international competitiveness. Because of globalization and technological advancements, the nature of work has changed in society. Workers now require a variety of skills to adapt to the constantly evolving requirements in the new knowledge-based and competitive economy (Buchel, 2001; Grayson 2004). It is therefore important from a public policy perspective that graduates use their postsecondary education in their subsequent employment.

Most studies to do with the phenomenon of education-job mismatch look at level of education (Robst 2007a). When working in a position below one's level of study, skills learnt in formal education may not be fully used. In the existing literature, over-education is often synonymous with being over-skilled (Buchel 2001), however some authors argue that measuring education-match in 
terms of years of schooling is a poor measure of skills and abilities. For example, Di Pietro and Urwin (2003) find that in general, level of education was correlated with skill use on the job, but people could be adequately educated in terms of their educational level and still be under-skilled in their job requirements, and vice-versa.

Vertical mismatch of education (mismatch of level of education and job) is not the only form of educational mismatch. Another important form of mismatch is horizontal mismatch (i.e. mismatch of field of study and job). Paying attention to field of study is important because it allows for analysing different types of skills; education provides not only general human capital, but particular fields of study provide occupationally specific skills for the job market (Robst 2007a; Van de Werfhorst 2002). In his study, Walters (2004) cross-tabulates a question about whether employers requested a specific postsecondary credential for the job, and compares this to whether graduates used the skills and knowledge they acquired in their postsecondary education on the job. The author finds that there is a strong connection for occupationally specific disciplines, but not for general ones.

Education mismatch can have important labour market consequences for the mismatched individual, employers, and society. For example, Roterman (1999) and Garcia-Espejo and Ibanez (2006) find that job mismatches are an important cause of job dissatisfaction. Wolbers (2003) finds that education-job mismatches lead to employee turnover. Wolbers (2003), Robst (2007a), Roterman (1999), Boudarbat and Montmarquette (2009), as well as Heijke, Meng, and Ris (2003) show a clear negative effect that education-job mismatch has on wages / job status. Van Smoorenburg and Van der Velden (2000) show that a proper match between education and employment reduces the need for further training within the firm.

In addition, because postsecondary institutions are being increasingly evaluated in terms of how they transfer practical labour market skills to their students (Krahn and Bowlby 1999), they can benefit from obtaining a more in-depth understanding of how and why individuals are obtaining employment related to their education. For example, individual courses or even entire programs may be modified based on the extent of, and reasons for educational mismatch. A better understanding of the match graduates of postsecondary institutions have with their subsequent employment can help society maximize returns on its postsecondary education investments. Redpath (1994) notes that a 
society's economic development depends upon it having a proper match with its educational system. Garcia-Espejo and Ibanez (2006) argue that for society at large, a proper job-education match "leads to social benefits, such as productivity increase and welfare, which derive from an efficient use of the active population's human capital" (p. 141).

Despite its importance, a preliminary review of the research indicates that a relatively high percentage of Canadian graduates do not have a job that matches what they studied in school. Barely over half the graduates of 1995 had jobs closely related to their field of study, two years after graduation (Boudarbat and Montmarquette 2009). This paper examines the determinants for obtaining employment that is related to one's university degree in Canada. This measure of mismatch encompasses not only the level of study, but also the field of study as well (a relatively neglected area of research), and will help explain this phenomenon. Data is from the Follow-up of Graduates survey, class 2000, the most comprehensive and up to date labour market study of postsecondary graduates in Canada, and represents a selected sample of 9335 Canadian university graduates.

\section{Brief review of the of education-job match literature}

\section{Theory}

Witte and Kalleberg (1995) note that there is theoretical importance to the issue of education-job match, as it brings attention to the understanding of how and why individuals are matched to their employment, which is a concern of many labour market specialists. Even though in our study we do not aim to test theoretical aspects of education-job match, we think it is relevant to examine how some labour market theories would interpret job-education match/mismatch.

In Human capital theory, there are numerous aspects to human capital besides education, such as experience, training, etc. This theory paints a positive picture of higher education, portraying it as providing the skills needed to perform complex jobs, making people more productive, thus sustaining economic growth (Walters 2004). Workers with the most human capital (or at least with the optimal combination thereof) are the most productive, and thus earn the highest wages.

In Human Capital theory, educational mismatch can be viewed as part of an efficient labour market (Robst 2007a), i.e. a temporary phenomenon to replace one form of human capital to gain another. 
Upon acquiring the lacking human capital, a promotion to a higher position will follow, to more adequately match the level of human capital that a worker possesses (Chiswick and Miller 2007, Robst 2007a).

On the other hand, Credentialism theory questions whether postsecondary education provides necessary skills used in employment. In the credentialist viewpoint, skills are by and large acquired on the job, and employers see education as a predictor of the future productivity and trainability of employees (Garcia-Espejo and Ibanez 2006). Collins (1979) argues that education is more to socialize people in appropriate cultures than to teach job skills. Roterman (1999) comments on Collins' work, and notes that credentialists would argue that an Arts graduate earns less because of a "lack of familiarity with corporate culture or ambivalence to working in the private sector and not so much from a lack of skills" (p34). Collins argues that employers use credentials obtained by graduates as a form of currency, hiring only those who have the highest degree papers, but these papers have very little actual worth.

In credentialist theories, education mismatch by level or field of employment is problematic but might be expected. If a graduate spends an extra few years earning a particular degree, it might demonstrate to the employer that the graduate's intelligence and their abilities to be disciplined and to learn have presumably already been demonstrated in school. The employer might therefore hire this graduate ahead of someone without this degree, or with a lower degree, even if it is not necessary to perform the job itself. However, as the credentialist critique goes, the three years and many tens of thousands of dollars this investment takes is not worth its subsequent screening advantage to employers.

The Job-matching (or Assignment theory) is based on the idea that the labour market is composed of jobs of many different skill and experience levels, as well as workers of many different skill and experience levels (Sattinger 1993). In such theories, it is beneficial to both employers and employees for the most skilled (i.e. the most educated) workers to occupy the most skilled positions. Workers prefer to work in a job that matches their skills and education, as it increasing feelings of usefulness, and allows workers to have more "control over their job" (Sorenson and Kalleberg 1981) which enables them to command higher salaries. Employers prefer such a match because workers who are fully employing their competencies will maximize productivity for the firm, and as well, 
turnover is reduced (Jovanovic 1979).

In job-matching theories, mismatches are most often looked at by skills; however it is not difficult to extend this concept to mismatch by degree. Some degree fields are more in demand than others, and this might explain better labour market results of some disciplines (Storen and Arneson 2006). Presumably, a mismatch by degree would not allow one to use the skills and knowledge acquired in education on the job, and that people will suffer a wage effect and be compelled to change jobs until a better match is found.

Finally, the Technological change theory is based on the idea that in the modern and advanced economy, the rate of technology progresses quite rapidly. Workers with seniority within the firm are therefore likely to have less of an education-job match compared to newer workers, who received a more recent education, i.e. more relevant to the technology of the day (Chiswick and Miller 2007). In the same vein, because of differences in the levels of (technological) development of the countries of origin and destination, immigrants from less-developed countries are less likely to have a technology component to their schooling that is relevant to the labour market in the advanced host countries. Thusly, immigrants from less-developed countries are more likely to be overeducated than immigrants from developed countries (Chiswick and Miller 2007).

In terms of how this might be related to mismatch by education, it might be presumed that graduates who were hired at one point because their degree was appropriate for the job requirements, might find that this same degree, because of technological advancements, becomes less relevant than another degree. Under this theory, education mismatch should increase over time.

\section{Applied studies}

Most studies on education-job mismatch focus on how level of education affects match. However, a careful examination of the literature reveals there have been a growing number of articles pertaining to job mismatch by education degree field, as well as job mismatch by degree generally.

Wolbers 2003; Grayson 2004; Garcia-Espejo and Ibanez 2006; Robst 2007a; Krahn and Bowlby 1999; Storen and Arnesen 2006; and Heijke, Meng and Ris 2003, find that graduates from occupation-specific programs have a much higher degree of match than those in the more general 
programs. This is attributable to the fact that these such programs provide specific skills meant for the job market (Robst 2007a).

Storen and Arnesen (2006), and Heijke, Meng and Ris (2003) look at how the possession of general skills affect the match. General skills can either increase or decrease the likelihood of a match, depending on the field. For example, Storen and Arnesen (2006) find that in general, low levels of leadership slightly decreases match, which would be consistent, as it lowered job outcomes in general. Those that see themselves as having strong innovative, professional ability decreases match, (to the authors' surprise) while having good language skills decreased the match, which was attributed to the fact that many "Humanities" graduates had strong language abilities. Heijke, Meng and Ris (2003) find that having a high level of adaptability decreases match, which is likely attributable to the fact that those who can adapt might be less inclined to obtain employment in a field that they studied in school.

Also as far as academic achievements go, the higher the postsecondary educational level, the more likely the match (Wolbers 2003; Robst 2007a; Krahn and Bowlby 1999). Robst (2007a) also finds that the more recent the degree, the more likely the match, which might be attributable to the fact that people most likely took their most recent degree to specifically to find work in the labour market. Good grades during school also affect the education-job match (Grayson 2004; GarciaEspejo and Ibanez 2006; and Storen and Arnesen 2006). This might be attributable to the fact that employers view this as an indicator of ability to excel at the subject-related skills (Grayson 2004).

The education-job match is also found to be associated with some characteristics of the job. For instance, having a full-time job is associated with an increased match (Wolbers 2003). Having a permanent job generally is as well (Wolbers 2003; Witte and Kalleberg 1995; Krahn and Bowlby 1999), though this is not always the case, as in some situations having a temporary contract increases the match (Garcia-Espejo and Ibanez 2006).

There appears to be some discrepancy with firm size, as Witte and Kalleberg (1995) show that for males, working in a larger firm is negatively associated with education-job match (with no significant connection for females) whereas Wolbers (2003) finds that in larger firms the match is generally better. Witte and Kalleberg (1995) as well as Wolbers (2003) hypothesize that a larger firm might increase the match, because there are more positions available for graduates to find a 
position that matches their skills. Witte and Kalleberg (1995) also alternatively-hypothesize however, that a large firm might have more room for advancement within the company, so an initial match might be taken away after promotion opportunities.

Those who found work in Blue-collar positions or lower tier services had less of a match than whitecollar or professional professions (Witte and Kalleberg 1995; Garcia-Espejo 2006; Krahn and Bowlby 1999). This is likely attributable to the fact that the higher the position, the more likely it would be to require specific credentials, and thus a postsecondary education.

Obtaining a job through a connection negatively affects the education-job match (Grayson 2004). This might explain why proper match doesn't always lead to salary benefits (Allen and De Wert 2007; Allen and Van der Velden 2001). Robst (2007b) shows that the effect of mismatch on wage depends upon the different reasons for accepting mismatched positions. For example, for men, the salary penalty ranges from $18 \%$ to $29 \%$, when giving reasons such as job location, family constraints, working conditions, or that no matching jobs were available. A wage premium was found for men accepting mismatched positions for pay and advancement reasons.

As for demographic factors, there appears to be some contradictions concerning the effects of age, as Krahn and Bowlby (1999) found that older workers had a slightly higher match over younger workers, while Robst (2007a), Wolbers (2003), and Witte and Kalleberg (1995) find the opposite. Other demographic results show that people who were never married, as well as handicapped individuals have less of a match. Whites and Asians have less of a match than Blacks and Hispanics (Robst 2007a). Galarneau and Morissette (2008) document that a large proportion of immigrants to Canada with university degrees are in jobs with low educational requirements. The highest rates of mismatch are observed among immigrants from Southern and Southeast Asia. Jones and Sloane (2009) also provide evidence that the disabled are significantly more likely to be mismatched in the labour market. Being female slightly increases the likelihood of match in some studies (Wolbers 2003; Witte and Kalleberg 1995; Robst 2007a), slightly decreases its likelihood in others (Krahn and Bowlby 1999), and makes no difference in others (Garcia-Espejo and Ibanez 2006; Storen and Arnesen 2006). This discrepancy is difficult to explain.

People have many reasons for accepting a position outside one's own degree field, and such reasoning depends on the individual. Of course, there will always be facilitating and restricting 
factors for someone to choose a job that is related to their field of study, but ultimately in a free society, it is individuals themselves who will choose what job they take. Along these lines, Heijke, Meng, and Ris (2003) specifically examine the characteristic of motivation, and its effect on match. They show that the people, who felt it important to use their knowledge and skills on the job, have the higher match.

\section{Data and analysis}

\section{Data}

In this paper, we use data from the Follow-up of Graduates Survey - Class of 2000 (2000 FOG). The National Graduates Survey 2000, conducted in 2002, and its follow-up study, the 2000 FOG, conducted in 2005, are studies designed to gauge the link between postsecondary education and career outcomes of graduates two and five years after graduation. These labour market results include such indicators as salary, satisfaction with employment, and education-job match. It is a vast reservoir of information on the subject, and was carried out by Statistics Canada, in collaboration with Human Resources and Skills Development Canada (HRSDC) and thus is reliable and comprehensive.

The target population of the 2000 FOG consists of individuals who had obtained or satisfied the requirements of a university, college, or trade school degree/diploma/certificate from a public Canadian postsecondary institution in the year 2000. The study was collected via computer-assisted telephone, using a set questionnaire, from the period April 27th, 2005 to July 24th, 2005. The overall response rate for the FOG is $68.5 \%$, and has a final sample size of 34,304. (Follow-up of Graduates Survey - Class of 2000 - User Guide).

For the purpose of our study, we focus only on graduates with a university degree (Bachelor, Masters, or Doctorate), who were 25-60 at the time of the interview (5 years after graduation), who held a job during the week preceding the interview, and who did not take any further education since graduating in 2000. In total, 9335 graduates meet these four criteria.

\section{Methodology}

In the FOG study, the information on education-job match is based on response to the following 
question: "How closely is the (main) job you held last week related to your certificate, diploma or degree?" Three choices are given to graduates: 1) Closely related; 2) Somewhat related; 3) Not related. To focus on the determinants of obtaining a close match, we will use a binary measure, of whether graduates have a job that is closely related to their degree (value 1), or otherwise (value 0 ). Then, we consider a logit model $^{1}$ to determine the variables that are associated with the close match.

For the potential determinants of (closely) match, we break them down into three general categories: 1) Education characteristics; 2) Employment characteristics; and 3) Demographic characteristics. We also control for a variety of other characteristics.

\section{Education characteristics}

Education characteristics are among the main determinants of the education-job match. We will examine four concepts: 1) Field of study; 2) Level of study; 3) Grades; and 4) Recent work/school experience.

Field of study is interesting to investigate, as there are numerous types of programs that postsecondary institutions offer. Some forms of education are more vocationally oriented, in the sense that they provide specific content that graduates would expect to use in the job market. The 2000 FOG break down field of study into ten categories, and are slightly reorganized in our study (see Table 1). The level of education completed by graduates was seen to be another important determinant of education-job match in the literature. As mentioned earlier, we focus exclusively on university-level graduates (Bachelor's, Master's, and Doctorate).

Grades are also expected to have a strong positive correlation with education job match and thus are also looked at in this section. One possible weakness with the way this is collected in the 2000 FOG data is that it is a self-assessment of grades, i.e. grades compared to others, which can display an upwards bias. We will keep the responses as they are seen in the FOG survey because this format is suitable for our purposes; with individuals appearing 1) Top 10\% of class grades; 2) Top 10-25\% of class grades; 3) Top 25-50\% of class grades; and 4) Below 50\% of class grades.

The final variable in this group is major activities before enrolling in the completed program. We

\footnotetext{
${ }^{1}$ A probit is also suitable when the dependent variable is dichotomous. However, both models (logit and probit) give similar results in practice (Greene, 2003).
} 
will check whether prior work experience (and thus, information on the labour market) provides an advantage regarding education-job match.

\section{Employment characteristics}

Employment characteristics allow us to see whether some job characteristics are associated with an education-job match. This variable includes: 1) Method used to obtain employment; 2) Full-time vs. part-time employment; 3) Permanence of employment; and 4) Industry.

For how job was obtained, we have broken this category down from ten into seven (see Table 1).

Full-time employment is defined as working 30 hours or more per week. For industry, we consider 19 categories, as shown in Table 1.

\section{Demographic characteristics}

The "Demographics" variable will also provide some relevant insight, as nearly all of the concepts we chose were explored in the literature. The demographic questions we will be exploring as independent variables are: 1) Sex; and 2) Family background.

In our study, the family background is based on the level of education obtained by the parents, as well as the use of a government student loan. We grouped together the highest level achieved between the parents, as it was assumed that there would be relatively few instances with one parent having obtained a much a higher level of education than their spouse.

The use of a government student loan in the family background is interesting to consider, because it is an indicator of family wealth. Indeed, eligibility for a government student loan is only granted if the parents make less than a certain income; it is thus likely that people would have different job market considerations if this is required, and therefore it would likely affect the match. 


\section{Controls}

Several control variables are included in the logistic regression: 1) Province of employment; 2) Studied full-time vs. part-time; 3) Marital status; 4) Handicap; 5) Member of a visible minority group; 6) Age; and 7) Immigration status when entering program.

Province of employment was chosen to account for differences between provincial labour markets. We group together the provinces of Atlantic Canada, and chose to omit the territories. The territories were excluded from the scope of the survey.

Studied full-time vs. studied part-time would be interesting to control for, because whether a student devotes their entire effort into education might be different from those who did not, or those who did a mix of activities. To our knowledge, no study has looked before at this variable in connection with education-job match.

Handicap was included as a control variable because it allows us to see how being disabled affects job-education match. Age is listed as age in years at the time of the interview (i.e., in 2005).

Similar to Robst (2007a), we control for racial background because discrimination possibly will play a role in education-job mismatch, and use the concept Member of a visible minority group. Immigration status when entering program is also interesting to control for, because immigrants have different labour market outcomes than Canadian citizens, and it will be interesting to see how being educated in Canada will affect the match. It has been documented that immigrants to Canada have less favourable labour market results than Canadians, although these results appear to be present but less severe when their university degree is obtained in Canada (Ferrer, Green, and Riddell 2004; Alboim, Finnie, and Meng 2005; Gilmore and Le Petit 2008). It would be interesting to see how this translates to an education-job match when the degree is obtained in Canada when entering program.

\section{Empirical results}

\section{Descriptive statistics}

All statistics are presented in Table 1. Overall, $64.9 \%$ of graduates said their job closely matched 
their education, $22.5 \%$ said it was somewhat related, and $12.6 \%$ said it was not related at all.

In field of study, as was the case with the previous NGS/FOG studies, it would appear that the so called "soft science" credentials such as "Business", "Education", and "Social Sciences \& Law" were awarded more than "hard science" credentials such as "Engineering", "Mathematics/ Computer/ Information sciences", and "Health sciences" (Krahn and Bowlby 1999). "Business" made up the largest category of graduates in 2000 , at $19.3 \%$ of the sample, followed by "Education" (16.3\%), and "Social Sciences \& Law" (18.7\%).

In level of study, almost four out of five graduates in our sample (77.9\%) had Bachelor degrees, $18.6 \%$ had a Masters degree, and 3.5\% had a Doctorate. As for grades, it is quite obvious from the self-ranking system used in the National survey of graduates that graduates rank themselves upwards as far as their own grades are concerned. For example, 30.7\% of those surveyed felt their grades were in the top $10 \%$ of the class, and more than two thirds of those surveyed, (67.3\%) felt they were somewhere in the top $25 \%$ in their class for grades. Only $9 \%$ felt they were in the bottom $50 \%$ of their class.

As far as the major activity before graduation, more than half the sample (53.2\%) listed their major activity before entering their program as going to school, while nearly a third $(32.1 \%)$ were working; $10.2 \%$ listed a combination of the two. A small percentage (2.3\%) listed taking care of family as their number one activity, and $2.2 \%$ said they were doing something else (other) before entering their university program.

Demographic characteristics allow for seeing what kind of people make up our sample of 2000 university graduates. Females make up 59\% of our population. It would appear that Canadian graduates rely heavily on government support, as $41.3 \%$ reported using a government student loan as one of the two main sources of funding for all of their postsecondary education.

Approximately $37 \%$ of graduates had at least one parent holding a university degree, and $64 \%$ had a parent with at least some postsecondary education. Approximately $23 \%$ had parents whose highest level of education was a high school degree, and $12.6 \%$ had parents who had not obtained a high school diploma. Overall, it seems that Canadian graduates have parents who are well-educated. This is in line with the Drolet (2005) study, which finds that parents' education stand out as being an 
important determinant in the decision to attend university.

As for employment characteristics, in terms of method used to obtain employment, it would appear that Canadian graduates obtain their jobs through a variety of sources. Approximately one quarter $(24.3 \%)$, were referred by a friend or family member, $26.9 \%$ answered a job ad, and $24.8 \%$ contacted the employer directly. $8.8 \%$ got their job through a head hunter, $4.7 \%$ got their job through their campus, and 3.0\% through an employment agency. 3.7\% listed another method.

Some additional employment characteristics found in Table 1 are that the vast majority of those in our sample, $92.4 \%$ listed they were working full-time, and $89.6 \%$ said they had a permanent job. Clearly, most graduates were full-time and permanent employees, which would appear to bode well for the educational system, although it should be noted that unemployed graduates were excluded from the sample.

By industry, "Educational Services" makes up the largest proportion with $26.9 \%$ of graduates working in this industry, followed by "Health Care and Social Assistance" (14.2\%), "Professional, Scientific and Technical" (12.6\%), and "Public Administration" (10.2\%). It is apparent that most 2000 graduates do not work in primary sector industries.

As for the control variables, briefly, many of the figures represent the relatively young age of the graduates (33 years in 2005; 28 at the time of graduation). In terms of marital status, most were married (58.3\% of our population). $19.2 \%$ of graduates considered themselves members of visible minorities, and as for the immigration status when entering program, $15.6 \%$ were immigrants, and only $1.70 \%$ were on a student visa, while the rest are Canadian-born.

As for province of employment, expectedly, Ontario, as the country's biggest province, made up the largest percentage where graduates were working (42.5\%), followed by Quebec, (23.5\%), British Columbia (11.8\%), Alberta (10.7\%), and then Atlantic Canada (6.2\%). The other prairies provinces each made up less than $3 \%$ if the graduates, with Saskatchewan at 2.5\%, and Manitoba, $2.8 \%$.

In terms of studied full-time vs. part-time, most graduates in our sample considered themselves to be students first. Indeed, more than three quarters (76\%) of the 2000 graduates in our sample studied full-time, compared to $11.2 \%$ who studied part-time, and $12.8 \%$ who said they did a mix. 


\section{Logistic regression analysis}

In our logistic regression, the dependant variable takes value 1 if the (main) job is closely related to the graduate's degree, and 0 otherwise. Regression estimates are presented in Table 2. Variables will be compared through the means of an odds-ratio, which reveals how much more or less likely the variable is to produce a match compared to the base category. For example, a variable with an odds ratio of 0.5 means that that variable has half the likelihood of closely related match as the base category. Any odds ratio above 1 would mean it is more likely than the base category of producing a closely related match.

Field of study definitely influences the match, as most fields affect match strongly and their coefficients are highly significant. Not surprisingly, as documented in numerous studies, graduates in field specific programs had the best chance of finding employment related to their studies. Compared to the base category of "Social sciences \& Law", the highest education-job match was clearly "Health sciences", with an odds ratio 5.267, followed by "Education (2.018)", then "Mathematics/Computer/Information sciences" (1.951). Perhaps surprisingly, "Business" (1.835) was next ahead of "Engineering" (1.716), though "Business" is a broad program encompassing some field specific programs such as accounting, and some perhaps less so, like marketing. "Agriculture" was positive when compared to "Social sciences \& Law", but not significant, while "Physical and Life sciences" and "Other" were negative but not significant. The fields with the least incidence of match were "Arts" with an odds ratio of 0.588 (significant at 10\%), and "Humanities", at 0.584 .

For level of study, results suggest that the higher the degree, the better the match, with a Masters degree obtaining an odds ratio of 1.325 , and a Doctorate degree (odds ratio $=2.539$ ) having the strongest probability of a match of all degree levels. Regarding grades, each lower grade category had progressively less of an education-job match, though not all categories were statistically significant. Compared to the top 10\% of class grades, the category of top 10-25\% has a negative but not statistically significant coefficient. Those who were considered to be in the top 25 to $50 \%$ of their class had a likelihood of match 0.580 times that of the top 10\%. Finally, the bottom $50 \%$ had a likelihood of match 0.265 times that of the top $10 \%$. 
Those who worked before entering their program had the least poor incidence of mismatch compared to the base category, with an odds ratio of 0.564 . This was followed by those whose major activity was going to school (0.544). For reasons that cannot be explained at the moment, those who both went to school and worked before entering their program had the highest incidence of mismatch, at 0.434 the odds. Yet, we find that the coefficients on the three categories "Going to school before program", "Working before program" and "Working \& going to school before program" are not statistically different. These three categories cover $96 \%$ of graduates.

By gender, females were very slightly negative when compared to males, and this was not significant. It would appear here that gender is not a determinant of education-job match.

The level of education achieved by the parents of the graduates does not seem to matter for the most part. Compared to the base category of graduates whose parents' highest level of education was less than a secondary degree, there was only a single category of the eight categories of parental education that has a significant coefficient. Interestingly, when the highest level of education completed by the graduates' parent was a trade's degree, this noticeably reduced the education-job match with an odds ratio of 0.598 (significant at the $5 \%$ level). Having a post-graduate degree, some postsecondary education, and a secondary education produced slightly negative coefficients, while having unidentified postsecondary education, and a bachelor degree produced slightly positive coefficients, but none of these results are significant.

In the same vein, the requirement of a student loan did not significantly affect the education-job match. Those who required a loan had a slightly negative coefficient, but the latter is not significant.

With regard to the method used to obtain employment, next to the base category of graduates who had found employment through a referral, only those who found their job through their campus produced significant results, at 1.775 the odds ratio (significant at the $10 \%$ level). All other methods produced positive but insignificant coefficients, except finding employment through an employment agency, which produced a negative but insignificant coefficient. It would appear that the method used to obtain employment does not seem to matter for the most part for education-job match.

Having a full-time job strongly increase the likelihood of education-job match, with an odds ratio of 2.227, whereas having a permanent job only very slightly increases match, but the difference is not 
statistically significant.

Regarding industry, this turns out to be the single most significant determinant of all the variables, as all the categories of industries have large and statistically significant coefficients. What is immediately evident is how negative each of the other industries are compared to the base category of "Educational Services". The industry with the least incidence of education-job mismatch in comparison was "Professional, Scientific and Technical" with an odds ratio of 0.359 , followed by "Health Care and Social Assistance" (0.347), "Other Services except public Administration" (0.245) and then "Information and Cultural Industries" (0.199). At the bottom end was "Construction" (0.078), "Retail Trade" (0.068), “Accommodation and Food Services" (0.061), and lastly, "Wholesale Trade" (0.057). It would appear that the strongest match being in the upper tier sectors, and the worst match being in the lower tier ones.

\section{Control variables}

Briefly, we will examine the results of some of the control variables. By province, compared to the base category of working in the province of Ontario, the only province with a significant result was Quebec, which displays an odds ratio of 1.631. Saskatchewan, Atlantic Canada, and British Columbia, are all slightly positive, while Alberta and Manitoba are slightly negative, but none of the odds ratios are statistically significant. As for age, the coefficient for this variable produced a slightly negative but insignificant coefficient. Increased age reduced the likelihood of match, but to a limited extent. The fact that age did not seem to matter is somewhat surprising, as it might be expected that people would have different motivations for working at different ages.

Marital status makes no significant difference with regard to match. As for studied full-time vs. parttime, it appears that studying full-time significantly increases the probability of education-job match. Compared to the based category of studying full-time, those who studied part-time had an odds ratio of 0.736 (significant at the $10 \%$ level), while those who studied a mix of full and parttime had an odds ratio of 0.704 (significant at the $5 \%$ level).

Being handicapped decreased match slightly, with an odds ratio 0.617 (significant at the 10\% level). Likewise, being a member of a visible minority group has a negative coefficient, but the difference is not significant. Finally, the fact of being an immigrant decreases the probability of education-job 
match by $28 \%$, and this impact is significant at the $5 \%$ level). Moreover, possessing a student visa produces a negative but non-significant coefficient.

\section{Discussion}

In our study, education characteristics significantly affect the education-job match among university graduates. For example, almost all the categories in the field of study variable proved noticeable and significant. This is not surprising as these fields provide specific skills for specific occupations in the labour market, while the more general programs are not geared for specific careers, and thus would presumably have less of a match. Most of the articles in our study make the distinction between these types of skills, and some (Robst 2007a; Garcia-Espejo and Ibanez 2006; and Wolbers 2003) specifically note the importance of having education-job match in these types of programs, where the labour market penalties for mismatch is more severe. In addition, both the level of study and grades influence the education-job match as well. Again, these results are consistent with the findings of studies on education-job match that we have looked at.

By field of study, Wolbers (2003); Grayson (2004); Garcia-Espejo and Ibanez (2006); Robst (2007a); Krahn and Bowlby (1999); Storen and Arneson (2006); Heijke, Meng and Ris (2003) show the more field specific programs obtain a higher match, while Wolbers (2003); Robst (2007a); Krahn and Bowlby (1999) all clearly show that the higher the level of education, the better the match. Grayson (2004), Garcia-Espejo and Ibanez (2006), and Storen and Arnesen (2006), all show the better grades obtained during education increases the match.

These results would appear to give some tentative support to the Human Capital theory, at least according to the logic used by Grayson (2004), who in his articles views knowledge and skills developed in school as pure human capital in the pursuance of career outcomes, one of which being the education-job match. The fact that the large majority of university graduates, $64.90 \%$ said they felt their job was closely related to their education seems to show that most graduates are indeed using what they learnt in school in their employment. Furthermore, this relation is affected by how and what they studied in school, as well as how they did in school. If the credential was all that mattered, it would seem that such details would matter less than they did.

As for Demographic characteristics, these did not appear to matter very much. The sex of the 
graduate, as well as nearly all of the various characteristics of family background that we looked at, i.e. the highest level of education obtained by parents, as well as the requirement of a loan, produced for the most part produced insignificant coefficients in our logistic regression analysis.

The evidence behind demographic characteristics increasing or decreasing match is mixed. The sex of the graduate for example, had some studies with females having a higher match (Wolbers 2003; Witte and Kalleberg 1995; Robst 2007a), other studies showing males with the higher match (Krahn and Bowlby 1999), and this making no difference in others (Garcia-Espejo and Ibanez 2006; Storen and Arnesen 2006).

As for level of education achieved by parents as well as the requirement of a loan, as noted, these variables have not been investigated before in any study we have found. This in and of itself is a little surprising, as people come from many walks of life and of many backgrounds, and it would seem logical that this would affect education-job match outcomes.

As for Employment characteristics, the results were mixed in our study, with some strongly affecting the match, while others being insignificant in our regression analysis. The single determinant with the strongest influence on match in our entire study is the industry the graduate works in. Certain industries, such as "Educational services", had match rates many times that of other industries, such as "Accommodation and Food Services" and "Wholesale Trade". Other characteristics of the job itself, such as working full-time also strongly positively affected the match. Wolbers (2003) finds that full-time employment is associated with education-job match. As found by Krahn and Bowlby (1999), the industry a graduate worked in heavily affected match. This makes sense as some industries like teaching or professional services would seem far more likely to require specific education credentials to be allowed in it, whereas industries like trades and accommodation would seem far less inclined to require such education.

The variables in employment characteristics which unexpectedly do not seem to matter are how the job was obtained, as well as the permanence of employment. These results were perhaps surprising as the studies which included these characteristics clearly demonstrate that they affect the match. For example, for the method used to obtain employment, our regression analysis gave mostly insignificant results for the most part. This is in clear contrast to the Grayson (2004) study. 
The fact that using a head hunter has no significant impact on match is a bit surprising, as these are people who are paid to find specific careers for people with specific credentials. It is also interesting that those who found their job through a campus placement agency is the only category that produced statistically significant and positive results. Perhaps this is because campus placement agencies would have connections to certain industries, and be specifically geared to set up graduates from its universities with jobs in their fields.

All in all, our results are mostly line with previous studies. Clearly, some variables are strongly associated with an education-job match, while other variables don't seem to matter very much. Interestingly, for several of the categories which indicated a mix of activities (i.e. those who did a mix of working and studying as their major activity before graduation, those who studied a mix of both full-time and part-time for studied full-time or part-time...), this lead to a noticeable and significant decrease in match. It would appear that being focused on one's activity is associated with a higher match.

It would also appear that the variables associated with the choices made by graduates (i.e. the field and level of study, grades, studying full-time vs. part-time, the types of employment chosen afterwards, etc.) matter far more than the variables than variables that are pre-determined (demographic characteristics, being handicapped, etc.). Perhaps these results are therefore also as a positive observation. It would seem to bode well that any graduate in Canada, regardless of their sex, parental background or social status can obtain employment that matches what they learnt in school.

\section{Conclusion}

Canada has put a tremendous investment into its postsecondary education system. If one of the main functions of education is to provide skills that will be used in subsequent employment, then it would be considered an inefficient use of resources for both individuals and society as a whole for graduates not to use their education in their jobs. This notion has spawned a great deal of research comparing education and its relation to subsequent employment. In most studies, the concept of education-job match is looked at in terms of years of schooling required to get the job and years of schooling obtained, however the level of education is not the only choice students make when taking education. We chose to look at this education-job match through work and its relation to the degree 
obtained, which encompasses both the level and field of study obtained in a graduate's education.

Our research explores the determinants of education-job match using data for a sample of Canadian university graduates from the 2000 FOG. Our results are generally in line with similar studies. A large percentage of graduates (64.90\%) found their education to be "closely related" with their job. By and large, education characteristics affect match, employment characteristics affect match to a fair extent, while demographic characteristics are far less important.

For our education characteristics, in particular, the field and level of school, as well as grades obtained, highly increase the education-job match, in accordance with previous studies. We also attempt to look at the activity before entering program to see if a better understanding of the labour market would increase match, though our results here are inconclusive. The activity before entering one's program affects match, but in ways in which we did not foresee; working before entering one's program produced a better match when compared to those who just studied, but those who did both had the weakest connection to match, while those who neither studied nor worked had the highest match. The latter result should be considered with caution, since less than 5\% of graduates were neither studying nor working before starting their university program.

For our employment characteristics, in accordance with previous studies, working full-time (vs. working part-time), and the industry of employment in particular, strongly affect the education-job match. Conversely, the permanence of employment has little effect on match in our study, as did method used to obtain employment, in contrast to what our review of the literature had lead us to expect.

Demographic characteristics, such as sex, highest level of education achieved by parents, and the requirement of a loan did not produce significant results for the most part. By and large, we felt it positive that demographic characteristics did not affect match, as it shows that employment outcomes, at least in the form of match, are not particularly influenced by discriminatory factors.

Our study contributes to the research in this area by accounting for several variables which have not been looked at before to our knowledge; the requirement of a loan and parents education, both of which allow us to explore how family background affect match. We also use the variable "activity before entering one's program" which allows us to see whether knowledge of the labour market 
benefits match.

For future research, it would be interesting to study the requirement of a degree to work on the job, to skills learnt from education used on the job, as in Walters (2004). It also would be interesting to question graduates about their understanding of the labour market to investigate how this affects choices. Other future areas of interest to study include looking at labour market consequences of match, as well as how match changes over time. These latter two variables are found in the 2000 FOG, and would allow for a more practical understanding of educational-job mismatch.

Furthermore, it would allow for the exploration of such labour market theories as Job matching and Technological change theories, providing for a better theoretical understanding.

Although not the key part of our study, we have mentioned that labour market results of educationjob match results are mixed. Witte and Kalleberg (1995) note that a close fit between training and employment is not necessarily a good thing. In many cases, maintaining a very close fit between training and employment would represent a career constraint, as higher positions might require new skills sets, not learnt in postsecondary education. 


\section{BIBLIOGRAPHY}

Alboim, Naomi, Ross Finnie, and Ronald Meng (2005). "The Discounting of Immigrants' Skills in Canada: Evidence and Policy Recommendations." IRPP Choices 11, no. 2.

Allen, Jim and Egbert De Weert (2007) "What do Educational Mismatches Tell us about Skills Mismatches? A Cross-country Analysis”, European Journal of Education, Vol. 42, No. 1, (p59-73).

Allen, Jim and Rolf Van der Velden (2001) "Educational Mismatches vs Skill Mismatches: Effects on Wage, Job Satisfaction, and on the Job Search", Oxford Economic Papers, 3, (p434-452).

Borghans, L. and A. de Grip (2000) (eds) "The Overeducated Worker? The Economics of Underutilization of Skills”, Edward Elgar, Chltenham, (260 pages).

Boudarbat, Brahim; and Claude Montmarquette (2009) "Choice of Fields of Study of University Canadian Graduates: the Role of Gender and their Parents' Education”, Forthcoming, Education Economics, Vol. 17, Issue 2, pages 185 - 213.

Buchel, Felix (2001) "Overqualification: Reasons, Measurement Issues and Typological Affinity to Unemployment", Extract from: Descy, Pascaline; Tessaring, Manfred (2001) (eds.) "Training in Europe Second Report on Vocational Training Research in Europe 2000: Background Report. (Cedefop Reference series)", Luxembourg: Office for Official Publications of the European Communities, (3 volumes); ISBN 92-896-0034-0. (p453-560).

Chiswick, Barry R., and Paul W. Miller (2007) “The International Transferability of Immigrants' Human Capital Skills”, Discussion Paper Series, IZA DP No. 2670 (27 pages).

Collins, Randal (1979) "The Credential Society An Historical Sociology of Education and Stratification", Academic Press, New York.

Di Pietro, Giorgio and Peter Urwin (2003) "Education and Skills Mismatch in the Italian Graduate Labour Market”, Royal Economic Society Annual Conference 2003, (26 pages).

Drolet, Marie (2005), "Participation in Post-secondary Education in Canada: Has the Role of Parental Income and Education Changed over the 1990s?," Statistics Canada - Analytical Studies Branch Research Paper Series, 11F0019MIE No. 243.

Emery, Herb (2004 draft) “Total and Private Returns to University Education in Canada: 1960-2030 and in Comparison to other Post-Secondary Training", Prepared for: Higher Education in Canada, John Deutsch Institute for the Study of Economic Policy, February 13-14, 2004 (37 pages).

Galarneau, Diane and René Morissette (2008) "Immigrants' education and required job skills", Perspectives (December), Statistics Canada - Catalogue no. 75-001-X (p. 5-18). 
Garcia-Espejo, Isabel, and Marta Ibanez (2006) "Education-Skill Matches and Labour Achievements among Graduates in Spain”, European Sociological Review, Vol. 22 Number 2 (p141-155).

Gilmore , Jason, and, Christel Le Petit (2008) “The Immigrant Labour Force Analysis Series The Canadian Immigrant Labour Market in 2007: Analysis by Region of Postsecondary Education" The Immigrant Labour Force Analysis Series, Catalogue no. 71-606-X2008004, ISSN 1914-6299 ISBN, 978-1-100-10273-3 (32 pages).

Grayson, Paul J. (2004) “Social Dynamics, University Experiences, and Graduates' Job Outcome”, British Journal of Sociology of Education, Vol. 25, No. 5, (p609-627).

Greene, W. H. (2003). Econometrics Analysis. $5^{\mathrm{e}}$ edition. Prentice Hall.

Halaby, Charles N. (1994) “Overeducation and Skills Mismatch”, Sociology of Education, Vol. 67, No. 1. (p47-59).

Heijke, H., C. Meng, and C. Ris (2003) "Fitting to the job: the role of generic and vocational competencies in adjustment and performance", Labour Economics, Vol. 10 (p215-229).

Jones, M. K.; P.J. Sloane (2009) “Disability and Skill Mismatch”, IZA discussion paper no. 4430.

Jovanovic, B. (1979) “Job Matching and the Theory of Turnover", Journal of Political Economy, Vol. 87, (p972-990).

Krahn, Harvey and Jeffrey Bowlby (1999) "Education job-skills match; An Analysis of the 1990 and 1995 National Graduates Surveys", A Human Resources Development Canada Research paper, in collaboration with the Centre for Education Statistics. R-00-101E (85 pages).

Owram, Doug (1996) "Born at the Right Time: A History of the Baby Boom Generation”, Toronto: University of Toronto Press (392 pages).

Redpath, Lindsay (1994) "Education-job Mismatch Among Canadian University Graduates: Implications for Employers and Educators", The Canadian Journal of Higher Education, Vol. XXIV-2 (p89-113).

Robst, John (2007a). "Education and Job Match: The Relatedness of College Major and Work", Economics of Education Review, 26, (p397-407).

Robst, John (2007b) "Education, College Major, and Job Match: Gender Differences in Reasons for Mismatch", Education Economics, 15:2, (p159-175).

Roterman, Michelle L. (1999) "Is there a Value in an Arts Education? An Analysis Using the 1997 National Graduates Survey” Masters of Arts Thesis, University of Guelph (172 pages) 
Sattinger, Michael (1993) "Assignment Models of the Distribution of Earnings" Journal of Economic Literature Vol. XXXI, (p831-880).

Sorenson, Aage B., and Kalleberg, Arne L. (1981) "An Outline of a Theory of the Matching of Persons to Jobs", Chapter 3: Sociological Perspectives on Labour Markets, edited by Ivar Berg, Academic Press.

Storen, Liv Anne and Clara Ase Arnesen (2006) "What Promotes a Successful Utilization of Competence in the Labour Market Five Years after Graduation? Does Vocational Higher Education Result in a Better Match than Academic Generalist Education?", Paper presented at the European Research Network on Transition in Youth - 2006 Workshop, Marseilles, 7-9 September 2006 (27 pages).

Van Smoorenburg, M.S.M. and R.K.W. Van der Velden (2000) "The Training of School-Leavers: Complementarity or Substitution?”, Economics of Education Review, Vol. 19, (p207-217).

Van de Werfhorst, Herman G. (2002) "Fields of Study, Acquired Skills and the Wage Benefit from a Matching Job", Acta Sociologica, Vol. 45:4, (p287 - 303).

Walters, David (2004) "The Relationship Between Postsecondary Education and Skill: Comparing Credentialism with Human Capital Theory", The Canadian Journal of Higher Education, Vol. 34, No. 2 (p97-124).

Witte, James C. and Arne L Kalleberg (1995) "Matching Training and Jobs: The Fit between Vocational Education and Employment in the German Labour Market", European Sociological Review, Vol. 11 No. 3. (p293-317).

Wolbers, Maareten H.J. (2003) "Job Mismatches and their Labour-Market Effects among SchoolLeavers in Europe", European Sociological Review, Vol. 19 No. 3, (p249-266).

OECD (2009) "Education at a Glance 2009" published on the responsibility of the SecretaryGeneral of the OECD, 96 pages.

Statistics Canada (2007) "National Graduates Survey (NGS)” *Presently unavailable online.

Statistics Canada Centre for Education Statistics "Microdata User Guide Follow-up of Graduates Survey Class of 2000 Public Use Microdata File". 
Table 1: Descriptive Statistics

\begin{tabular}{|c|c|}
\hline Variable & Proportion/mean \\
\hline \multicolumn{2}{|l|}{ Education-Job match } \\
\hline - Closely & 0.649 \\
\hline - Somewhat & 0.225 \\
\hline - Not at all & 0.126 \\
\hline \multicolumn{2}{|l|}{ Education Characteristics } \\
\hline \multicolumn{2}{|l|}{ Field of study: } \\
\hline - $\quad$ Education & 0.163 \\
\hline - Arts & 0.032 \\
\hline - Humanities & 0.077 \\
\hline - Social Sciences \& Law & 0.187 \\
\hline - Business & 0.193 \\
\hline - $\quad$ Physical and Life sciences & 0.061 \\
\hline - Mathematics/Computer/Information sciences & 0.055 \\
\hline - Engineering & 0.097 \\
\hline - $\quad$ Agriculture & 0.024 \\
\hline - Health sciences & 0.087 \\
\hline - Other & 0.023 \\
\hline \multicolumn{2}{|l|}{ Level of study: } \\
\hline - Bachelor & 0.779 \\
\hline - $\quad$ Master & 0.186 \\
\hline - Doctorate & 0.035 \\
\hline \multicolumn{2}{|l|}{ Grades: } \\
\hline - Top $10 \%$ of class grades & 0.307 \\
\hline - $\quad$ Top $10-25 \%$ of class grades & 0.366 \\
\hline - Top25-50\% of class grades & 0.172 \\
\hline - Below $50 \%$ of class grades & 0.009 \\
\hline - Grades unknown & 0.146 \\
\hline \multicolumn{2}{|l|}{ Activity before entering program: } \\
\hline - $\quad$ Going to school before program & 0.532 \\
\hline - Working before program & 0.321 \\
\hline Working \& going to school before program, & 0.102 \\
\hline - $\quad$ Taking care of family before program & 0.023 \\
\hline - Doing other before program & 0.022 \\
\hline \multicolumn{2}{|l|}{ Demographic Characteristics } \\
\hline Female & 0.590 \\
\hline
\end{tabular}




\begin{tabular}{|c|c|}
\hline Variable & Proportion/mean \\
\hline \multicolumn{2}{|l|}{ Family background } \\
\hline $\begin{array}{l}\text { Used a government student loan as one of the two main } \\
\text { sources of funding for all of their postsecondary education }\end{array}$ & 0.413 \\
\hline \multicolumn{2}{|l|}{ Parent's highest level of education: } \\
\hline - $\quad$ Parents post-grad & 0.160 \\
\hline - $\quad$ Parents bachelor & 0.210 \\
\hline - $\quad$ Parents postsecondary & 0.148 \\
\hline - $\quad$ Parents trade & 0.049 \\
\hline - Parents some postsecondary & 0.073 \\
\hline - $\quad$ Parents secondary & 0.229 \\
\hline - $\quad$ Parents less than secondary & 0.126 \\
\hline - $\quad$ Parents Other & 0.011 \\
\hline \multicolumn{2}{|l|}{ Employment Characteristics } \\
\hline \multicolumn{2}{|l|}{ Method used to obtain employment: } \\
\hline - $\quad$ Referred & 0.243 \\
\hline - $\quad$ Answered job ad & 0.269 \\
\hline - Contacted employer directly & 0.248 \\
\hline - Campus placement agency & 0.047 \\
\hline - $\quad$ Employment agency & 0.030 \\
\hline - Head hunter & 0.088 \\
\hline - $\quad$ Other method & 0.037 \\
\hline - $\quad$ Not stated & 0.038 \\
\hline Full-time job & 0.924 \\
\hline Permanent job & 0.896 \\
\hline \multicolumn{2}{|l|}{ Industry: } \\
\hline - $\quad$ Educational Services & 0.269 \\
\hline - Health Care and Social Assistance & 0.142 \\
\hline - Professional, Scientific and Technical & 0.126 \\
\hline - $\quad$ Public Administration & 0.102 \\
\hline - $\quad$ Manufacturing & 0.082 \\
\hline - $\quad$ Finance and Insurance & 0.068 \\
\hline - $\quad$ Information and Cultural Industries & 0.042 \\
\hline - $\quad$ Retail Trade & 0.030 \\
\hline - $\quad$ Other Services except public Administration & 0.025 \\
\hline $\begin{array}{l}\text { - Administrative and Support, Waste Management } \\
\text { and Remediation Services }\end{array}$ & 0.018 \\
\hline - Wholesale Trade & 0.017 \\
\hline - Arts, Entertainment and Recreation & 0.016 \\
\hline
\end{tabular}




\begin{tabular}{|c|c|}
\hline Variable & Proportion/mean \\
\hline - $\quad$ (Mining and Oil and Gas Extraction) & 0.014 \\
\hline - $\quad$ Transportation and Warehousing & 0.013 \\
\hline - $\quad$ Accommodation and Food Services & 0.009 \\
\hline - $\quad$ Utilities & 0.009 \\
\hline - $\quad$ Construction & 0.008 \\
\hline - $\quad$ Agriculture, Forestry, Fishing and Hunting & 0.005 \\
\hline $\begin{array}{l}\text { Real Estate and Rental Leasing, as well as } \\
\text { Management of Companies and Enterprises }\end{array}$ & 0.004 \\
\hline \multicolumn{2}{|l|}{ Control Variables } \\
\hline \multicolumn{2}{|l|}{ Province of employment: } \\
\hline - $\quad$ Atlantic Canada & 0.062 \\
\hline - Quebec & 0.235 \\
\hline - Ontario & 0.425 \\
\hline - Manitoba & 0.028 \\
\hline - Saskatchewan & 0.025 \\
\hline - $\quad$ Alberta & 0.107 \\
\hline - $\quad$ British Columbia & 0.118 \\
\hline \multicolumn{2}{|l|}{ Studied full-time vs. part-time: } \\
\hline - $\quad$ Studied full-time & 0.760 \\
\hline - $\quad$ Studied part-time & 0.112 \\
\hline - $\quad$ Studied a mix of full-time and part-time & 0.128 \\
\hline \multicolumn{2}{|l|}{ Marital status: } \\
\hline - $\quad$ Married & 0.583 \\
\hline - $\quad$ Separated/Divorced/Widowed & 0.039 \\
\hline - $\quad$ Single (never married) & 0.373 \\
\hline - $\quad$ Handicapped & 0.030 \\
\hline Member of a visible minority & 0.192 \\
\hline Age at interview & $\begin{array}{c}33.054 \\
(\text { Std.dev.=7.4) }\end{array}$ \\
\hline \multicolumn{2}{|l|}{ Immigration status when entering the program: } \\
\hline - Immigrant & 0.156 \\
\hline - $\quad$ Student visa & 0.017 \\
\hline \# observations & 9335 \\
\hline
\end{tabular}

Note: Data are weighted. Sample includes graduates, who had obtained a university degree in 2000 , who were 25 to 60 years old at the time of the interview (i.e. in 2005), and who hadn't taken additional programs since graduation 
Table 2: Results of Logistic Regression for Obtaining a Job Closely Related to Education

\begin{tabular}{|c|c|c|c|}
\hline$\underline{\text { Variable }}$ & $\underline{\text { Coefficient }}$ & $\frac{\text { Standard- }}{\text { error }}$ & $\underline{\underline{\text { Odds }}}$ \\
\hline \multicolumn{4}{|l|}{ Education Characteristics } \\
\hline \multicolumn{4}{|l|}{ Field of study (Ref. = Social sciences \& Law): } \\
\hline - $\quad$ Education & $0.702 * * *$ & 0.222 & $2.018 * * *$ \\
\hline - $\quad$ Arts & $-0.530 *$ & 0.29 & $0.588^{*}$ \\
\hline - $\quad$ Humanities & $-0.538 * * *$ & 0.201 & $0.584 * * *$ \\
\hline - $\quad$ Business & $0.607 * * *$ & 0.16 & $1.835 * * *$ \\
\hline - $\quad$ Physical and Life sciences & -0.139 & 0.194 & 0.870 \\
\hline $\begin{array}{l}\text { - Mathematics/Computer/Information } \\
\text { sciences }\end{array}$ & $0.668 * * *$ & 0.225 & $1.951 * * *$ \\
\hline - $\quad$ Engineering & $0.540 * * *$ & 0.175 & $1.716^{* * *}$ \\
\hline - $\quad$ Agriculture & 0.233 & 0.225 & 1.263 \\
\hline - $\quad$ Health sciences & $1.661 * * *$ & 0.204 & $5.267 * * *$ \\
\hline - $\quad$ Other & -0.529 & 0.383 & 0.589 \\
\hline \multicolumn{4}{|l|}{ Level of study (Ref. = Bachelor's degree): } \\
\hline - $\quad$ Master's degree & $0.282 * * *$ & 0.107 & $1.325 * * *$ \\
\hline - $\quad$ Doctorate degree & $0.932 * * *$ & 0.189 & $2.539 * * *$ \\
\hline \multicolumn{4}{|l|}{ Grades (Ref. = Top 10\% of class): } \\
\hline - $\quad$ Top $10-25 \%$ of class & -0.184 & 0.115 & 0.832 \\
\hline - $\quad$ Top $25-50 \%$ of class & $-0.545 * * *$ & 0.143 & $0.580 * * *$ \\
\hline - $\quad$ Below $50 \%$ of class & $-1.327 * * *$ & 0.386 & $0.265 * * *$ \\
\hline \multicolumn{4}{|l|}{$\begin{array}{l}\text { Major activity before entering program (Ref. } \\
\text { =Not working or going to school before entering } \\
\text { program: }\end{array}$} \\
\hline - $\quad$ Going to school before program & $-0.608 * * *$ & 0.211 & $0.544 * * *$ \\
\hline - $\quad$ Working before program & $-0.573 * * *$ & 0.216 & $0.564 * * *$ \\
\hline $\begin{array}{l}\text { - Working \& going to school before } \\
\text { program }\end{array}$ & $-0.834 * * *$ & 0.264 & $0.434 * * *$ \\
\hline \multicolumn{4}{|l|}{ Demographic Characteristics } \\
\hline - $\quad$ Female & -0.091 & 0.105 & 0.913 \\
\hline \multicolumn{4}{|l|}{$\begin{array}{l}\text { Family Background (Ref. }=\text { Didn't require a } \\
\text { loan): }\end{array}$} \\
\hline - $\quad$ Required a loan & -0.018 & 0.099 & 0.982 \\
\hline \multicolumn{4}{|l|}{$\begin{array}{l}\text { Parent's highest level of education (Ref. }= \\
\text { Parents less secondary): }\end{array}$} \\
\hline - $\quad$ Parents secondary & -0.197 & 0.158 & 0.821 \\
\hline
\end{tabular}




\begin{tabular}{|c|c|c|c|}
\hline$\underline{\text { Variable }}$ & Coefficient & $\frac{\text { Standard- }}{\text { error }}$ & $\frac{\text { Odds }}{\text { Ratio }}$ \\
\hline - $\quad$ Parents some postsecondary & -0.203 & 0.227 & 0.817 \\
\hline - $\quad$ Parents Trade & $-0.514 * *$ & 0.213 & $0.598 * *$ \\
\hline - $\quad$ Parents postsecondary & 0.112 & 0.195 & 1.119 \\
\hline - $\quad$ Parents Bachelor & 0.023 & 0.167 & 1.023 \\
\hline - $\quad$ Parents Post-grad & -0.066 & 0.168 & 0.936 \\
\hline \multicolumn{4}{|l|}{ Employment Characteristics } \\
\hline \multicolumn{4}{|l|}{$\begin{array}{l}\text { Method used to obtain employment (Ref.= } \\
\text { Referred): }\end{array}$} \\
\hline - $\quad$ Answered job ad & 0.035 & 0.129 & 1.036 \\
\hline - $\quad$ Contacted employer directly & 0.113 & 0.128 & 1.120 \\
\hline - Campus placement agency & $0.574 *$ & 0.311 & $1.775^{*}$ \\
\hline - $\quad$ Employment agency & -0.118 & 0.262 & 0.889 \\
\hline - $\quad$ Head hunter & 0.234 & 0.188 & 1.264 \\
\hline - $\quad$ Other method & 0.324 & 0.283 & 1.383 \\
\hline Full-time job & $0.801 * * *$ & -0.169 & $2.227 * * *$ \\
\hline Permanent job & 0.146 & -0.159 & 1.158 \\
\hline \multicolumn{4}{|l|}{ Industry (Ref. = Educational Services): } \\
\hline $\begin{array}{ll}- & \text { Agriculture, Forestry, Fishing and } \\
& \text { Hunting } \\
\end{array}$ & $-1.718 * * *$ & -0.4 & $0.179 * * *$ \\
\hline - $\quad$ Mining and Oil and Gas Extraction & $-1.709 * * *$ & -0.517 & $0.181^{* * *}$ \\
\hline - Utilities & $-1.670^{* * *}$ & -0.382 & $0.188^{* * *}$ \\
\hline - $\quad$ Construction & $-2.545 * * *$ & -0.372 & $0.078 * * *$ \\
\hline - $\quad$ Manufacturing & $-1.663 * * *$ & -0.229 & $0.190^{* * *}$ \\
\hline - $\quad$ Wholesale Trade & $-2.861 * * *$ & -0.318 & $0.057 * * *$ \\
\hline - $\quad$ Retail Trade & $-2.683 * * *$ & -0.246 & $0.068 * * *$ \\
\hline - $\quad$ Transportation and Warehousing & $-2.275 * * *$ & -0.332 & $0.103^{* * *}$ \\
\hline - $\quad$ Information and Cultural Industries & $-1.616^{* * *}$ & -0.283 & $0.199 * * *$ \\
\hline - $\quad$ Finance and Insurance & $-2.479 * * *$ & -0.251 & $0.084^{* * *}$ \\
\hline - $\quad$ Professional, Scientific and Technical & $-1.024 * * *$ & -0.216 & $0.359^{* * *}$ \\
\hline $\begin{array}{ll} & \text { Administrative and Support, Waste } \\
& \text { Management and Remediation Services }\end{array}$ & $-2.045^{* * *}$ & -0.426 & $0.129 * * *$ \\
\hline - $\quad$ Health Care and Social Assistance & $-1.060 * * *$ & -0.214 & $0.347 * * *$ \\
\hline - $\quad$ Arts, Entertainment and Recreation & $-1.686^{* * *}$ & -0.425 & $0.185^{* * *}$ \\
\hline - $\quad$ Accommodation and Food Services & $-2.792 * * *$ & -0.496 & $0.061 * * *$ \\
\hline $\begin{array}{ll} & \text { Other Services except public } \\
& \text { Administration } \\
\end{array}$ & $-1.407 * * *$ & -0.348 & $0.245 * * *$ \\
\hline - $\quad$ Public Administration & $-1.758 * * *$ & -0.2 & $0.172 * * *$ \\
\hline $\begin{array}{l}\text { - Real Estate and Rental Leasing, as well } \\
\text { as Management of Companies and }\end{array}$ & $-2.060 * * *$ & -0.715 & $0.127 * * *$ \\
\hline
\end{tabular}




\begin{tabular}{|c|c|c|c|}
\hline$\underline{\text { Variable }}$ & $\underline{\text { Coefficient }}$ & $\frac{\text { Standard- }}{\text { error }}$ & $\frac{\text { Odds }}{\text { Ratio }}$ \\
\hline \multicolumn{4}{|l|}{ Enterprises } \\
\hline \multicolumn{4}{|l|}{ Control Variables } \\
\hline \multicolumn{4}{|l|}{ Province of employment $($ Ref. $=$ Ontario): } \\
\hline - $\quad$ Atlantic Canada & 0.116 & -0.135 & 1.123 \\
\hline - $\quad$ Quebec & $0.489 * * *$ & -0.126 & $1.631^{* * *}$ \\
\hline - $\quad$ Manitoba & -0.018 & -0.163 & 0.982 \\
\hline - Saskatchewan & 0.118 & -0.171 & 1.125 \\
\hline - $\quad$ Alberta & -0.07 & -0.147 & 0.932 \\
\hline - $\quad$ British Columbia & 0.051 & -0.156 & 1.052 \\
\hline \multicolumn{4}{|l|}{$\begin{array}{l}\text { Studied full- time vs. part-time (Ref. =Studied } \\
\text { full-time): }\end{array}$} \\
\hline - Studied part-time & $-0.307^{*}$ & -0.173 & $0.736^{*}$ \\
\hline - $\quad$ Studied a mix of full-time and part-time & $-0.351 * *$ & -0.14 & $0.704 * *$ \\
\hline \multicolumn{4}{|l|}{ Marital status $($ Ref. $=$ Single $):$} \\
\hline - $\quad$ Married & 0.162 & -0.102 & 1.176 \\
\hline - $\quad$ Separated, divorced or widowed & 0.347 & -0.243 & 1.415 \\
\hline - $\quad$ Handicapped & $-0.483^{*}$ & -0.292 & $0.617^{*}$ \\
\hline - $\quad$ Member of a visible minority & -0.219 & -0.154 & 0.803 \\
\hline - $\quad$ Age at interview & -0.014 & -0.009 & 0.986 \\
\hline \multicolumn{4}{|l|}{$\begin{array}{l}\text { Immigration status when entering program (Ref. } \\
\text { = Canadian Born): }\end{array}$} \\
\hline - $\quad$ Immigrant & $-0.332 * *$ & -0.167 & $0.718 * *$ \\
\hline - $\quad$ Student visa & -0.342 & -0.298 & 0.710 \\
\hline
\end{tabular}

\# Observations: 9335 . * Significant at 10\%; ** significant at 5\%; *** significant at $1 \%$.

The coefficient on "Student visa" should be interpreted with caution, since this group includes very few graduates (see Table 1). 